Pak. j. sci. ind. res. Ser. B: biol. sci. 2017 60(2) 59-64

\title{
Grass Diversity in the Historical Kalash Valley, District Chitral, Hindukush Range, Pakistan
}

\author{
Fazal Hadia* and Muhammad Ibrar \\ ${ }^{a}$ Center of Plant Biodiversity, University of Peshawar, Peshawar, Pakistan \\ ${ }^{b}$ Department of Botany, University of Peshawar, Peshawar, Pakistan
}

(received October 31, 2016; revised December 22, 2016; accepted December 27, 2016)

\begin{abstract}
The present study was carried out to enlist the grass flora of Kalash valley, Pakistan their ecological characteristics and ethnobotanical uses. A total of 36 grass species belonging to 29 genera were identified. Poa was the dominant genus with 4 (11.11\%) species followed by Avena, Bromus, Hordeum and Lolium represented by $2(5.55 \%)$ species each. The remaining genera had one species each. Ecological characteristics revealed that $23(63.89 \%)$ species were rarely occurring, $9(25 \%)$ were common and 4 (11.11\%) species were abundantly occurring in the valley. Life form spectra showed that therophytes were dominant with $24(66.67 \%)$ species followed by hemicryptophytes with $8(22.22 \%)$ species, chamaephytes $3(8.33 \%)$ and geophytes had one $(2.78 \%)$ species. Leaf size spectra revealed that $26(72.22 \%)$ species were nanophylls, 4 (11.11\%) were microphylls and 3 (8.33\%) were mesophylls. 27 (75\%) species were growing on dry places and 9 (25\%) were growing on wet soils. Similarly, $33(91.67 \%)$ were fodder species, $3(11.11 \%)$ were food species and $2(5.55 \%)$ species were used for thatching purposes in the valley. The present information will be useful for further ecological and biological researches on the grasses in this dry temperate region of Pakistan.
\end{abstract}

Keywords: grasses, ethnobotanical characteristics, Kalash valley, district Chitral

\section{Introduction}

Pakistan is naturally gifted with diverse flora and altitudinal variation from sea level upto more than $8000 \mathrm{~m}$ height. Kalash valley is situated in district Chitral and comprises of three sub valleys viz: Bumburet, Rumbor and Birir. The valley is famous due to its inhabitants that are considered to be the descendants of Alexander the Great.

Floristic composition provides basic information about any ecological, phytogeographical and management studies of the plants of an area. It shows the diversity of species of an area and reflects the effects of soil erosion, overgrazing and deforestation on the plants (Rafay, 2013). Floristic composition also highlights the dependence of local community of an area on plant resources and point outs the hazards on the plants due to the anthropogenic activities.

District Chitral lies between $35^{\circ} 15^{\prime} 06^{\prime \prime}$ to $36^{\circ} 55^{\prime} 32^{\prime \prime}$ north latitudes and $71^{\circ} 11^{\prime} 32^{\prime \prime}$ to $73^{\circ} 51^{\prime} 34^{\prime \prime}$ east longitudes to extreme north west of Pakistan with total area of $14850 \mathrm{~km}^{2}$ (GOP, 1998). The district has important strategic and geographic location and bounded on the east with district Ghizer of Gilgit-Baltistan, on the south with districts of Dir and Swat, on the west

*Author for correspondence; E-mail: hadibotany@yahoo.com with Nooristan province of Afghanistan and on the north-west Wakhan Corridor (Afghanistan) is located (Fig. 1-2). This district has very ancient human history and the peoples are living here from about 4000 years and the area remained an important route for many invaders to South Asia including the Alexander the Great, Scythians, Changez Khan and many others (Shah, 2014). The district Chitral is influenced by Chinese, Greek, Iranian, Mongolian, Tatars and Turk cultures. Many languages like Dameli, Eastern Katviri, Gawar Bati, Gujari, Kalasha, Madaghlashti, Pashto, Phalura, Persian, Shikani, Wakhi and Yidga are also spoken at different and restricted places of Chitral in addition to the main language Kohwar (Chitrali) (Murtaza, 1962).

The present study area "Kalash valley" is located to the extreme south-west of district Chitral and is bounded in the west with Nooristan province of Afghanistan and to the other parts of Chitral by three sides. The valley comprises of major Muslim community along with minority Kalash that are still practicing an old, unique, indigenous and polytheistic religion "Kalasha". The Kalash people remained rulers of Chitral valley for almost five centuries (332-712 AD), but are now restricted only to three sub-valleys viz: Bumburet, Birir and Rumbor, collectively known as Kalash valley or Kafiristan. The Kalash valley is located in the dry 


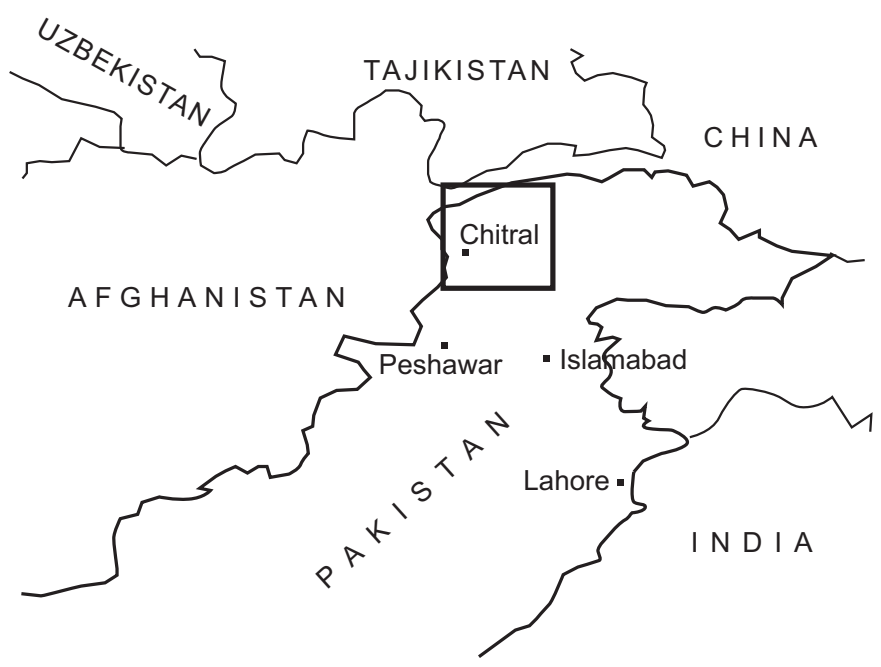

Fig. 1. Map of Pakistan on the globe showing Chitral Valley in black square box.

temperate zone at $71^{\circ} 46^{\prime} 55^{\prime \prime}$ east longitudes and $35^{\circ}$ $50^{\prime} 32^{\prime \prime}$ north latitudes having pleasant summers and very cold winters characterized by heavy snow fall with annual average rain of $250-400 \mathrm{~mm}$. The commonly cultivated crops of the area are maize and wheat and various vegetables are also cultivated by the locals. The natural forest mainly consists of Cedrus deodara (Roxb. Ex Lamb.) G.Don, Juniperus communis L., Juniperus exelsa M. Bieb., Pinus gerardiana Wall. ex Lamb., Pinus wallichiana A. B. Jackson, Quercus baloot Griffith and Quercus incana Lindl.. Cattle rearing are also good source of food and income generations for the locals and each of the sub-valleys has its own rangeland and pastures used by the locals for fodder of their cattle.

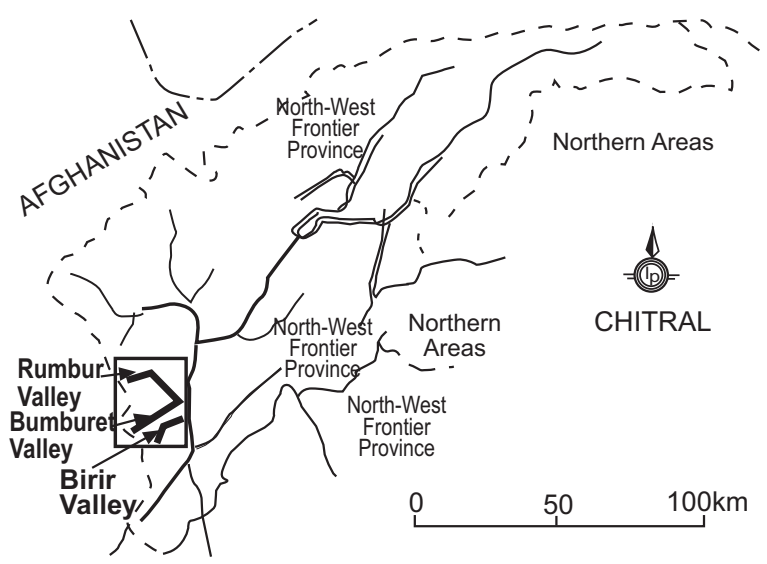

Fig. 2. Map of district Chitral showing the study area in black square box.
No floristic information is available for Kalash valley. The present study was therefore, designed to enlist the rangeland and other grass species of the Kalash valley, district Chitral, Pakistan.

\section{Materials and Methods}

The study area was thoroughly investigated from April 2013 to March 2015 for the collection of rangeland grasses. Specimens were collected, pressed, dried and identified through Flora of Pakistan (Ali and Qaiser, 1993-2015; Ali and Nasir, 1989-1991; Nasir and Ali, 1970-1989) and other available literature in the herbarium of Department of Botany, University of Peshawar. The data on the local uses of these grasses was obtained through interviewing the local inhabitants with the help of a questionnaire. The plants were classified into different classes on the basis of ecological characteristics obtained by following the study of Raunkiaer (1934) and Hussain (1989).

\section{Results and Discussion}

The present study revealed that there were 36 grasses belonging to 29 genera as shown in Table 1. Floristic composition showed that Poa was leading genus with 04 species (11.11\%) followed by Avena, Bromus, Hordeum and Lolium with 02 (5.55\%) species each while the remaining genera were represented by one species each (Fig. 3). The life form spectra showed that therophyte was dominant group with 24 (66.67\%) species followed by hemicryptophytes having 8 $(22.22 \%)$ species, chamaephytes $3(8.33 \%)$ species 


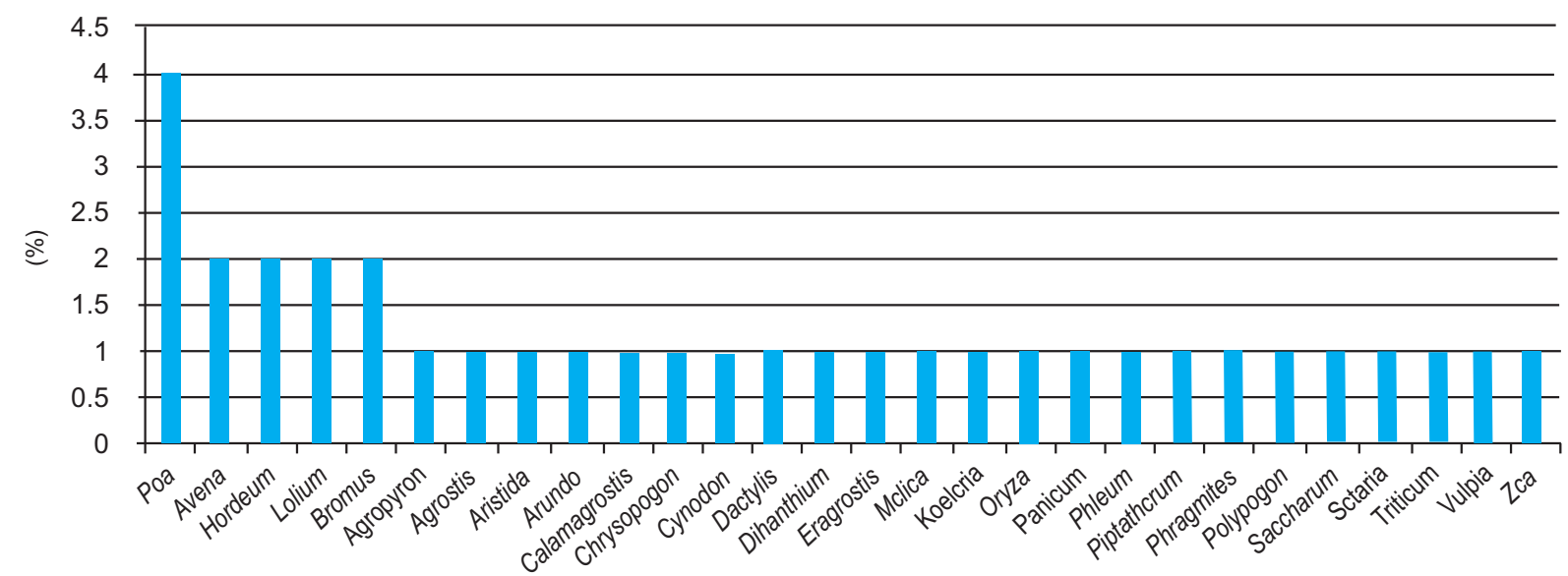

Fig. 3. Number of species in each genus.

and geophytes with one (2.78\%) species only (Fig. 4). The leaf size spectra revealed that nanophylls were dominant with $26(72.22 \%)$ species followed by microphylls with 4 (11.11\%) and mesophylls with 3 (8.33\%) species (Fig. 5). Out of 36 grass species, 27 $(75 \%)$ were growing on dry and $9(25 \%)$ species on wet habitats. 23 (63.89\%) species were rarely occurring, $9(25 \%)$ were common and $4(11.11 \%)$ species were abundantly occurring in the valley (Fig. 6). Similarly, $33(91.67 \%)$ were fodder species, $3(11.11 \%)$ were food species and $2(5.55 \%)$ species were used for thatching purposes (Fig. 7).

During summer the species distribution was at its maximum and genus Poa showed maximum number of species that revealed that the area is cool and dry and supports dwarf and light grasses in this subtropical

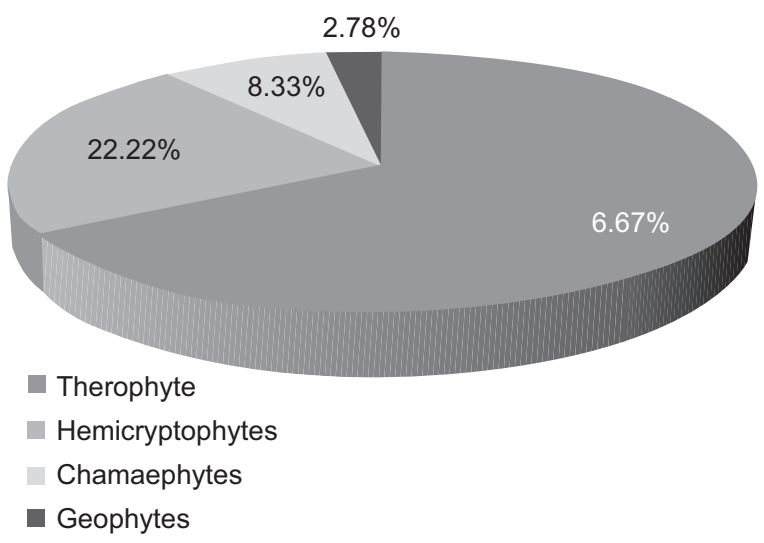

Fig. 4. Graphical representation of life form spectrum of grasses in Kalash valley. region. The extreme climatic conditions, overgrazing, over exploitation of plants and anthropogenic activities supported the annuals and short lived plants so the life

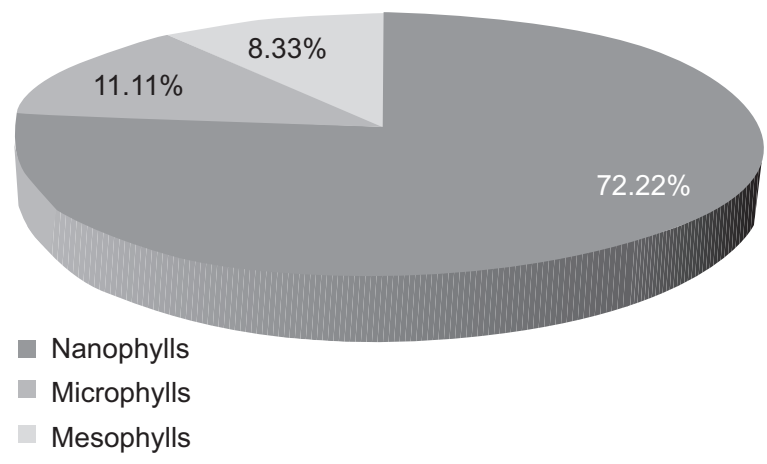

Fig. 5. Graphical representation of leaf size spectrum of grasses in Kalash valley.

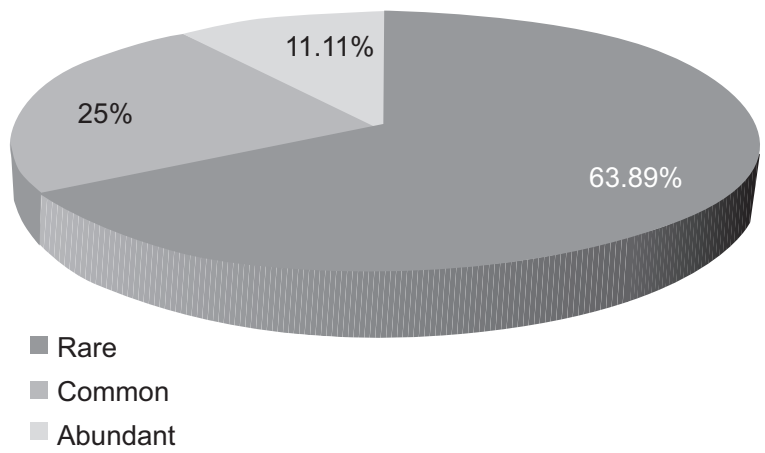

Fig. 6. Graphical representation of presence of grasses in Kalash valley. 
form was dominated by therophytes followed by hemicryptophytes and chamaephytes. Present findings are supported by other researchers (Badshah et al., 2013; Rafay, 2013; Qureshi, 2011; Durrani et al., 2010; Manhas et al., 2010; Guo et al., 2009). Similarly, few workers have worked out different aspects of plant resources of Chitral valley i.e. (Shah and Hussain, 2015; 2014; 2012; Hadi et al., 2013; Ali and Qaiser, 2009; Hussain et al., 2007; Shah et al., 2006; Hussain and Murad, 2004).

Table 1. Grasses, their ethnobotanical uses and ecological characteristics in Kalash valley, Hindukush range, district Chitral, Pakistan

\begin{tabular}{|c|c|c|c|c|c|c|c|c|c|c|}
\hline \multirow[t]{2}{*}{ S\# } & \multirow[t]{2}{*}{ Grass name } & \multirow{2}{*}{$\begin{array}{l}\text { Ethnobotanical } \\
\text { uses }\end{array}$} & \multicolumn{3}{|c|}{ Kalash valley } & \multicolumn{5}{|c|}{ Ecological characteristics } \\
\hline & & & $\mathrm{B}$ & $\mathrm{R}$ & $\mathrm{BR}$ & 1 & 2 & 3 & 4 & 5 \\
\hline 1 & Agropyron semicostatum Nees ex Steud & Fodder & - & + & + & $\operatorname{Re}$ & $\mathrm{Th}$ & $\mathrm{N}$ & M & $\mathrm{S}$ \\
\hline 2 & Agrostis viridis Gouan. & Fodder & - & + & - & $\mathrm{Re}$ & $\mathrm{Th}$ & $\mathrm{N}$ & $\mathrm{D}$ & $\mathrm{S}$ \\
\hline 3 & Aristida cynantha Nees ex Steud & Fodder & - & + & + & $\mathrm{Cm}$ & $\mathrm{H}$ & $\mathrm{N}$ & $\mathrm{D}$ & $\mathrm{S}$ \\
\hline 4 & Arundo donax L. & Thatching & + & - & - & $\mathrm{Re}$ & $\mathrm{Ch}$ & Mac & M & $\mathrm{S}$ \\
\hline 5 & Avena fatua $\mathrm{L}$ & Fodder & + & - & + & $\mathrm{Cm}$ & Th & $\mathrm{N}$ & $\mathrm{D}$ & $\mathrm{S}$ \\
\hline 6 & Avena sativa $\mathrm{L}$. & Fodder & + & + & + & $\mathrm{Cm}$ & $\mathrm{Th}$ & $\mathrm{N}$ & $\mathrm{D}$ & $\mathrm{S}$ \\
\hline 7 & Bromus danthoniae Trin. & Fodder & + & + & - & $\mathrm{Re}$ & Th & Mes & $\mathrm{D}$ & $\mathrm{S}$ \\
\hline 8 & Bromus tectorumbb L. & Fodder & + & + & - & $\operatorname{Re}$ & $\mathrm{Th}$ & Mes & $\mathrm{D}$ & $\mathrm{S}$ \\
\hline 9 & Calamagrostis emodensis Griseb. & Fodder & + & - & - & $\mathrm{Re}$ & G & Mes & M & $\mathrm{S}$ \\
\hline 10 & Chrysopogon echinulatus (Nees ex Steud.) W. Wats & Fodder & + & + & - & $\operatorname{Re}$ & $\mathrm{Th}$ & $\mathrm{N}$ & $\mathrm{D}$ & $\mathrm{S}$ \\
\hline 11 & Cynodon dactylon (L.) Pers. & Fodder & + & + & + & $\mathrm{Cm}$ & $\mathrm{H}$ & $\mathrm{N}$ & $\mathrm{D}$ & $\mathrm{S}$ \\
\hline 12 & Dactylis glomerata L. & Fodder & + & - & + & $\mathrm{Re}$ & Th & $\mathrm{N}$ & $\mathrm{D}$ & $\mathrm{S}$ \\
\hline 13 & Dichanthium annulatum (Forssk.) Stapf. & Fodder & - & - & + & A & $\mathrm{H}$ & $\mathrm{N}$ & M & $\mathrm{S}$ \\
\hline 14 & Echinochloa crusgalli (L.) P. Beauv. & Fodder & + & - & + & $\operatorname{Re}$ & $\mathrm{Th}$ & $\mathrm{N}$ & M & $\mathrm{S}$ \\
\hline 15 & Eragrostis poaeoides P. Beave. & Fodder & + & + & + & $\mathrm{Re}$ & $\mathrm{H}$ & $\mathrm{N}$ & M & $\mathrm{S}$ \\
\hline 16 & Hordeum murinum L. & Fodder & + & + & + & $\mathrm{Cm}$ & Th & $\mathrm{N}$ & $\mathrm{D}$ & $\mathrm{S}$ \\
\hline 17 & Hordeum vulgare L. & Fodder, food & + & + & + & $\operatorname{Re}$ & Th & $\mathrm{N}$ & $\mathrm{D}$ & $\mathrm{S}$ \\
\hline 18 & Koeleria gracilis Pers. & Fodder & - & - & + & $\operatorname{Re}$ & $\mathrm{H}$ & $\mathrm{N}$ & $\mathrm{D}$ & $\mathrm{S}$ \\
\hline 19 & Lolium rigidum Gaud. & Fodder & + & + & - & $\mathrm{Re}$ & Th & $\mathrm{N}$ & $\mathrm{D}$ & $\mathrm{S}$ \\
\hline 20 & Lolium temulentum L. & Fodder & + & - & - & $\mathrm{Re}$ & Th & $\mathrm{N}$ & $\mathrm{D}$ & $\mathrm{S}$ \\
\hline 21 & Melica inaequiglumis (Boiss.) Bor. & Fodder & + & - & - & $\mathrm{Re}$ & $\mathrm{H}$ & $\mathrm{N}$ & $\mathrm{D}$ & $\mathrm{S}$ \\
\hline 22 & Oryza sativa L. & Fodder, food & - & + & + & A & $\mathrm{H}$ & Mic & M & $\mathrm{S}$ \\
\hline 23 & Panicum antidotale Retz. & Fodder & - & - & + & $\mathrm{Re}$ & $\mathrm{Th}$ & $\mathrm{N}$ & $\mathrm{D}$ & $\mathrm{S}$ \\
\hline 24 & Phleum pretense L. & Fodder & + & - & - & $\mathrm{Cm}$ & $\mathrm{Th}$ & $\mathrm{N}$ & $\mathrm{D}$ & $\mathrm{S}$ \\
\hline 25 & Poa anпua $\mathrm{L}$. & Fodder & + & + & + & $\mathrm{Re}$ & $\mathrm{Th}$ & $\mathrm{N}$ & $\mathrm{D}$ & $\mathrm{S}$ \\
\hline 26 & Poa bulbosa L. & Fodder & - & - & + & $\mathrm{Cm}$ & Th & $\mathrm{N}$ & $\mathrm{D}$ & $\mathrm{S}$ \\
\hline 27 & Poa pratensis L. & Fodder & - & - & + & $\mathrm{Re}$ & Th & $\mathrm{N}$ & $\mathrm{D}$ & $\mathrm{S}$ \\
\hline 28 & Poa supina Schrad. & Fodder & - & + & - & $\mathrm{Re}$ & Th & $\mathrm{N}$ & $\mathrm{D}$ & $\mathrm{S}$ \\
\hline 29 & Piptatherum wendelboi Bor & Fodder & - & + & - & $\mathrm{Re}$ & $\mathrm{H}$ & $\mathrm{N}$ & $\mathrm{D}$ & $\mathrm{S}$ \\
\hline 30 & Phragmites karka (Retz.) Trin. ex Steud & Thatching & + & + & - & $\mathrm{Cm}$ & $\mathrm{Ch}$ & Mac & M & $\mathrm{S}$ \\
\hline 31 & Polypogon fugax Nees ex Steud & Fodder & - & - & + & $\mathrm{Re}$ & Th & Mic & M & $\mathrm{S}$ \\
\hline 32 & Saccharum spontaneum L. & Fodder & + & - & - & $\mathrm{Re}$ & $\mathrm{Ch}$ & Mac & $\mathrm{D}$ & $\mathrm{S}$ \\
\hline 33 & Setaria viridis (L.) P. Beauv. & Fodder & + & - & - & $\mathrm{Cm}$ & $\mathrm{Th}$ & $\mathrm{N}$ & $\mathrm{D}$ & $\mathrm{S}$ \\
\hline 34 & Triticum aestivum $\mathrm{L}$. & Fodder, food & + & + & + & A & Th & Mic & $\mathrm{D}$ & $\mathrm{S}$ \\
\hline 35 & Vulpia myuros (L.) Gmel. & - & - & + & + & $\mathrm{Re}$ & Th & $\mathrm{N}$ & $\mathrm{D}$ & $\mathrm{S}$ \\
\hline 36 & Zea mays L. & Fodder, food & + & + & + & A & Th & Mic & $\mathrm{D}$ & $\mathrm{S}$ \\
\hline
\end{tabular}

B = Bumburet; R = Rumbor; BR = Birir. (1) = Abundance; (2) = Life form; (3) = Leaf size; (4) = Habitat; (5) = Leaf appearance; $\mathrm{A}=$ abundance; $\mathrm{Ch}=$ Chamaephytes; $\mathrm{Cm}=$ Common; $\mathrm{D}=$ Dry; $\mathrm{G}=$ Geophytes $; \mathrm{H}=$ Hemicryptophytes; $\mathrm{L}=$ Leptophyll; $\mathrm{M}=$ Moist; $\mathrm{Mac}=$ Macrophyll; Mes = Mesophyll; Mic $=$ Microphyll; $\mathrm{N}=$ Nanophyll; Re = Rare; $\mathrm{S}=$ simple; Th = Therophytes . 


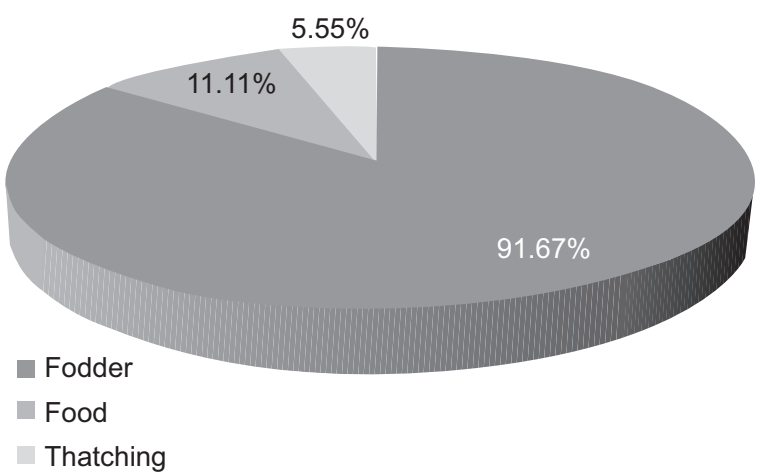

Fig. 7. Graphical representation of ethnobotanical uses of grasses in Kalash valley.

\section{Conclusion}

There is no authentic floristic and ethnobotanical data on plants of Kalash valley, therefore, the present study can provide $1^{\text {st }}$ ever record and first hand information specifically on the grasses and their potential use in historical Kalash valley. However, urbanization of the society has threatened the indigenous uses of these plants and the knowledge of old generation on these plants would be perished soon. Therefore, the present survey will document the precious indigenous knowledge on plants and will be helpful for further conservational and ethnobotanical studies.

The study might also be helpful for the same type of studies of much closed Nooristan Province of war affected Afghanistan.

\section{References}

Ali, H., Qaiser, M. 2009. The ethnobotany of Chitral valley, Pakistan with particular reference to medicinal plants. Pakistan Journal of Botany, 41: 2009-2041.

Ali, S.I., Qaiser, M. (eds). 1993-2015. Flora of Pakistan. Department of Botany, University of Karachi, Pakistan.

Ali, S.I., Nasir, Y.J. (eds). 1989-1993. Flora of Pakistan. Department of Botany, University of Karachi, and National Herbarium, PARC, Islamabad, Pakistan.

Badshah, L., Hussain, F., Sher, Z. 2013. Floristic inventory, ecological characteristics and biological spectrum of rangeland, District Tank, Pakistan. Pakistan Journal of Botany, 45: 1159-1168.

Durrani, M.J., Razaq, A., Muhammad, S.G., Hussain,
F. 2010. Floristic diversity, ecological, characteristics and ethnobotanical profile of plants of Aghberg rangelands, Balochistan, Pakistan. Pakistan Journal of Plant Sciences, 16: 29-36.

GOP, 1998. District Census Report of Chitral, Population Census Organization, Statistics Division, Islamabad, Government of Pakistan, Pakistan.

Guo, Q.S., Wang, X.F., Bar, G., Kang, Y., Hong, M., Pei, S.X., Zhang, F.G. 2009. Life form spectra, leaf character and hierarchical-synusia structure of vascular plants in Thuja sutchuehensis community. Ying Yong Sheng Tai Xue Bao, 20: 2057-2062.

Hadi, F., Razzaq, A., Rahman, A., Rashid, A. 2013. Ethnobotanical notes on woody plants of Rech Valley, Torkhow, District Chitral, Hindu-Kush range, Pakistan. Scholarly Journal of Agricultural Science, 3: 468-472.

Hussain, F., Shah, S.M., Badshah, L., Durrani, M.J. 2015. Diversity and ecological characteristics of flora of Mastuj valley, Chitral, Hindukush range, Pakistan. Pakistan Journal of Botany, 47: 495-510.

Hussain, F., Shah, S.M., Sher, H. 2007. Traditional resource evaluation of some plants of Mastuj, district Chitral, Pakistan. Pakistan Journal of Botany, 39: 339-354.

Hussain, F., Murad, A. 2004. Weed communities in the potato fields of Mastuj, District Chitral. Scientific Khyber, 17: 201-206.

Hussain, F., Badshah, L., Sanaullah, P., Durrani, M.J. 2004. Ethnobotany of timber wood species of South Waziristan, Pakistan. Pakistan Journal of Plant Sciences, 10: 9-16.

Hussain, F. 1989. Field and Laboratory Manual of Plant Ecology, University Grants Commission (UGC), Islamabad, Pakistan.

Manhas, R.K., Singh, L., Vasistha, H.B., Negi, M. 2010. Floristic diversity of protected ecosystems of Kandi Region of Punjab, India. New York Science Journal, 3: 96-103.

Murtaza, M.G. 1962. Nai Tarikh e Chitral. Public Art Press, Peshawar, Pakistan.

Nasir, E.J., Ali, S.I. (eds). 1970-1989. Flora of Pakistan. Department of Botany, University of Karachi, and National Herbarium, PARC, Islamabad, Pakistan.

Qureshi, R.A., Khan, W.A., Bhatti, G.R., Khan, B., Iqbal, S., Ahmad, M.S., Abid, M., Yaqub, A. 2011. First report on the biodiversity of Khunjerab National Park, Pakistan. Pakistan Journal of Botany, 
43: $849-861$

Rafay, M., Khan, R.A., Yaqoob, S., Ahmad, M. 2013. Floristic composition of grass species in the degrading rangelands of Cholistan desert. Pakistan Journal of Agriculture Science, 50: 599-603.

Raunkiaer, C., Gilbert, C.H., Fausboll, A., Tansley, A.G. 1934. The Life Forms of Plants and Statistical Plant Geography: Being the Collected Papers of C. Raunkiaer, 632 pp., Clrendon Press, Oxford, UK.

Shah, S.M. 2014. Ecological Evaluation of Rangeland
Resources in Mastuj Valley, Hindukush Range, Pakistan. Ph.D. Thesis. Department of Botany. University of Peshawar, Pakistan.

Shah, M., Hussain, F. 2012. Conservation assessment of plant resources of Chakesar valley, district Shangla, KPK, Pakistan. Pakistan Journal of Botany, (special issue) 44: 179-186.

Shah, S.M., Hussain, F., Ibrar, M. 2006. Floristic composition, life form and leaf size spectra of summer plants of Mastuj, District Chitral. PUTAJ Sciences, 13: 167-179. 